\title{
A Comparative Analysis of Inflation Hedging Characteristies of Real Estate and Financial Assets in Colombo
}

Bissertation Submitted to the University of Sini Jayewardenepura as a Bantial Tulfililment for the Requirement of the Final Examination of the M:Sc Estate Management and Valuation (Special) Degree

Full Name

Examination No

Registrattion No

Department

University

Dattes of Submissions

For evaluation

Corrected ffimall nexpontt:222.077.2014

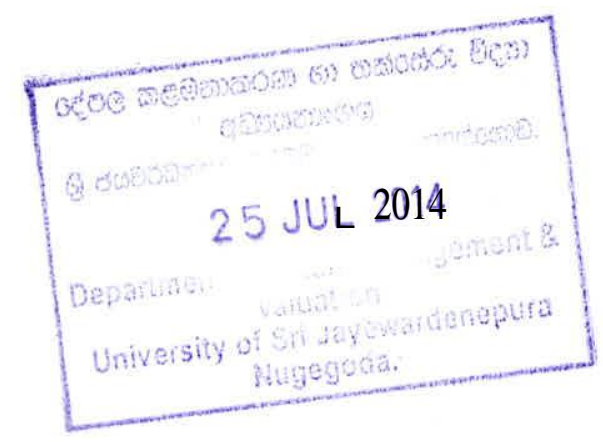

:Gardii Hewa Kankanange Nimesha Sakkurangani Wickramaratne

: REMV 93

: REMV 3781/09

: Bepartment of Estate Management and Valuation

: University of Shi Jayewardenepura

10.03 .2014
222.077 .2014 
The work described in this dissertation carried out under the supervision of Dr. P D Nimal and any content on this has not been submitted in whole or in part to any university or any other institute for another degree/examination or any other purpose.

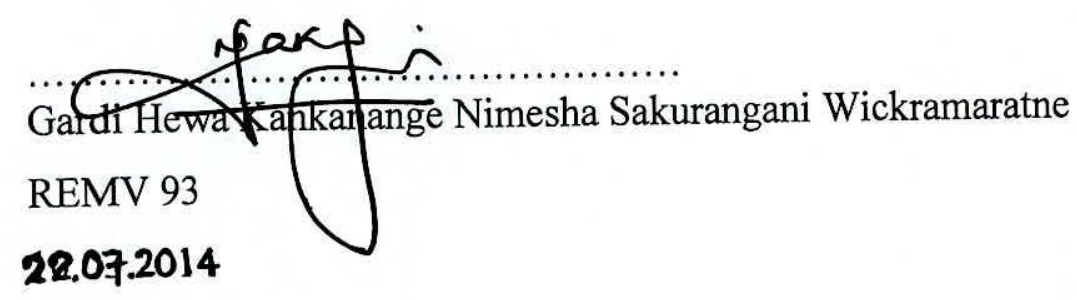


Hereby, I certify that Mrs Gardi Hewa Kankanange Nimesha Sakurangani Wickramaratne, REMV 93 duly completed the research titled A Comparative Analysis of Inflation Hedging Characteristics of Real Estate and Financial Assets in Colombo under my supervision.

Also it is declared that, this final report has been completed according to the instructions and suggestions made by the board of examiners.

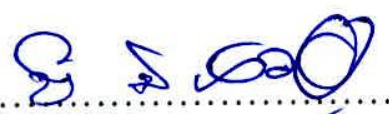

Signature of the supervisor

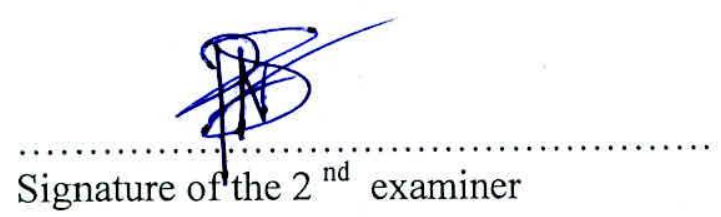

Signature and the official stamp of the Head 


\section{Acknowledgement}

This Dissertation would not have been possible without the guidance and the help of several individuals who in one way or another contributed and extended their valuable assistance in the preparation and completion of this study. It is a pleasure to convey my gratitude to them all in my humble acknowledgment.

First and foremost, I offer my utmost gratitude to my supervisor Dr. P D Nimal, The Head, Department of Finance, University of Sri Jayewardenepura, for his supervision, advice and guidance from the very early stage of this research as well as giving me extraordinary experiences throughout the work. Without him this dissertation would not have been completed or written. I am indebted to him more than he knows.

I gratefully acknowledge Prof. R G Ariyawansa, The Coordinator, M.Sc. in real estate and Valuation degree program, University of Sri Jayewardenepura, for his valuable advice and coordination to this dissertation. His involvement with his originality has triggered and nourished my intellectual maturity that I will benefit from, for a long time to come. Sir, I am grateful in every possible way.

Many thanks go in particular to Mr. Amila Wickramasinghe, Lecturer, and Department of Decision Science for his valuable advice, guidance and constant support for statistical analysis of this study for which I am eternally indebted.

My sincere thanks goes to all Senior Lecturers of the Department of Estate Management and Valuation, who gave me highly valuable suggestions for which I am eternally indebted.

I am heartily grateful to Top Management of the Department of Valuation, for giving me a tremendous support by giving property value details to make this task a success. 
Last but not the least I would like to thank my husband, parents and sisters for their unending support, encouragement and prayers. Without their support this work would not have been possible.

Finally, I would like to thank everybody who was important to the successful realization of this Dissertation, as well as expressing my apology that I could not mention personally one by one. 


\begin{abstract}
The general objective of this study is to comparatively analyse the inflation hedging characteristics of real estate and financial asset in Colombo. Three specific objectives were stated to achieve the above objective. First objective is to examine the inflation hedging ability of the real estate against actual, expected and unexpected inflation. Second is to examine the inflation hedging ability of the financial assets against actual, expected and unexpected inflation. Finally compare the inflation hedging ability of real and financial assets. Residential and commercial properties are taken for real estate and treasury bill and stock are used to represent the financial assets. Fama and Schewert 1977 framework and regression analysis is employed to analyse the data. The results support that residential properties are performed as good hedgers than commercial properties against actual inflation. Among the financial assets t-bills are performed as good hedgers than stocks against actual inflation. Since regression coefficients of all assets except stocks are less than 1, all assets are partially hedge against actual inflation. When expected and unexpected inflation are concerned t-bills are performed good hedgers against expected inflation while residential property plays best against unexpected inflation. Stocks are not hedgers against both expected and unexpected inflation.
\end{abstract}




\section{Table of Contents}

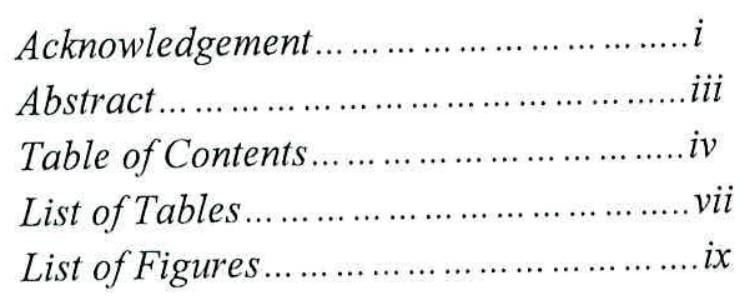

Contents

\section{CHAPTER ONE -Introduction}

1.1.Background of the study

1.2. Statement of the problem

1.3. Objectives of the study

1.4. Significant of the study

1.5.Methodology

1.5.1. Hypothesis

1.6.Limitations

1.7.Chapter organization

\section{CHAPTER TWO-Literature Review}

2.1. Introduction

2.2.Definition Theories and Concepts

2.2.1. Real Estate

2.2.2. Financial Assets

2.2.3. Hedging

2.2.4. Inflation

2.2.5. Inflation Hedge

2.2.6. Hedge against Inflation Theory

2.3. Real assets and financial assets as an investment tool

2.4. The effect of inflation: Real versus Financial Assets 
2.5.Empirical Studies relating to Asset Returns and Hedge against inflation

2.5.1. Rate of inflation

2.5.2. Asset Returns

2.6. Methods of analyzing the inflation hedging ability of asset returns

2.6.1. Fisher hypothesis

2.6.2. Co-integration approach

2.6.3. Correlation between nominal asset returns and inflation 30 rate

2.6.4. Real Return Variance 30

2.6.5. Added Variable Regression Method (AVRM) 31

2.6.6. OLS Regression Model 32

2.7.Real Estate and inflation hedging 35

2.8.Financial Assets and inflation hedging 35

\section{CHAPTER THREE - Research Design}

3.1.Introduction 37

3.2.Research design 37

3.3.Research methodology 39

3.4.Data and sample of data 40

3.4.1. Measures and variables 40

3.4.2. Sample and sample period 40

3.5. Data collection 40

3.6.Regression model specifications 41

3.7. Hypothesis 42

3.8.Data analysis 45

\section{CHAPTER FOUR - Background to the Research}

4.1.Introduction 
4.3.1. Return of real estate 48

4.4.Financial Market of Sri Lanka $\quad 49$

4.4.1. Capital Market (Stock Market) 49

4.4.2. Money Market; Treasury bill 51

4.5.Inflation of Sri Lanka $\quad 52$

4.5.1. Actual Inflation $\quad 52$

4.5.2. Expected and unexpected inflation $\quad 53$

\section{CHAPTER FIVE - Data Analysis}

5.1.Introduction $\quad 55$

5.2.Descriptive statistics for Asset returns and Inflation Rate 55

5.2.1. Real Estate Returns $\quad 55$

5.2.2. Financial Asset Returns 56

5.2.3. Frequencies for Assets Returns and inflation rate 56

5.2.4. Pearson rank correlation coefficients $\quad 59$

5.3.Inflation Hedging Ability of the Real Estate 59

5.3.1. Return of Residential Properties and Actual inflation 59

5.3.2. Return of Residential Properties and expected and 62 unexpected inflation

5.3.3. Return of Commercial Properties and Actual inflation 66

5.3.4. Return of Commercial Properties and expected and 68 unexpected inflation

5.4.Inflation Hedging Ability of the Financial assets 72

5.4.1. Return of T- bills and Actual inflation 72

5.4.2. Return of T-Bills and expected and unexpected inflation $\quad 75$

5.4.3. Return of Stocks and Actual inflation 79

5.4.4. Return of T-Bills and expected and unexpected inflation 81

5.5.Comparison of inflation hedging ability of all assets 85

5.5.1. Hedging against actual inflation 86

5.5.2. Hedging against expected and unexpected inflation 87 
CHAPTER SIX - Conclusions and Recommendations

6.1.Introduction

6.2.Research Findings

6.3.Recommendations

6.4. Further research area

References 


\section{List of Tables}

Table

Page

2.1. Description of variables relating residential new and existing housing prices

2.2. Summary of studies associated with asset returns and inflation

3.1. Research structure $\quad 38$

3.2. Independent and dependent variables $\quad 40$

3.3. Details of hypothesis 43

5.1. Frequencies for real estate returns 58

5.2. Pearson rank correlation coefficients between the asset returns 59 and the inflation rate

5.3. Regression result for residential return and actual inflation 60

5.4. Regression result for residential return and expected and 63 unexpected inflation

5.5. Regression result for commercial returns and actual inflation 67

5.6.Regression result for commercial return and expected and 70 unexpected inflation

5.7. Regression result for t-bills returns and actual inflation 73

5.8. Regression result for t-bill returns and expected and unexpected 76 inflation

5.9. Regression result for stock return and actual inflation 80

5.10. Regression result or stock returns and expected and unexpected 83 inflation

5.11. Summary of result for actual inflation and asset returns 86

5.12. Summary of result for expected and unexpected inflation and $\quad 87$ asset returns 


\section{List of Figures}

\section{Figure}

\section{Page}

1.1.Annual average percentage change of Colombo Consumer

Price Index (Base 1952 = 100) from $2003-2012$

4.1. No of properties in city of Colombo (2009)

4.2. Return of residential properties from $2003-2012$

4.3. Return of commercial properties from $2003-2012$

4.4. Annual average change of All Share Price Index for sample period of 2003 to 2012 (quarterly).

4.5. Interest rate of 3 month treasury bills from 2003 to 2012 (quarterly)

4.6. Annual Average Percentage change of Colombo Consumer

Price Index (Base 1952 = 100) from $2003-2012$

4.7. Movement of expected and unexpected inflation

2003- 2012 (Quarterly)

5.1. Histogram and normal curve for returns for commercial properties

5.2. Histogram and normal curve for returns for residential properties

5.3. Histogram and normal curve for returns of 3 months Treasury Bills

5.4. Histogram and normal curve for change of All Share Price Index

5.5. Histogram and normal curve for change of CCPI

5.6. Relationship between return of residential properties and actual inflation.

5.7. Relationship between return of residential properties and expected inflation.

5.8. Relationship between return of residential properties and unexpected inflation

5.9. Relationship between return of commercial properties and actual inflation.

5.10. Relationship between return of commercial properties and expected inflation. 
5.11. Relationship between return of commercial properties and unexpected inflation.

5.12. Relationship between return of T-bills and actual inflation. 73

5.13. Relationship between return of t-bill and expected inflation. 75

5.14. Relationship between return of t-bills and unexpected inflation. 76

5.15. Relationship between return of stocks and actual inflation. 79

5.16. Relationship between return of stocks and expected inflation. 82

5.17. Relationship between return of stocks and unexpected inflation. 82 


\section{CHAPTER ONE}

\section{Introduction}

\subsection{Background of the Study}

One of the objectives of holding an investment portfolio is to protect the purchasing power of investors and provide investors with a continuous positive real rate-of-return. However, it has been observed that during inflationary periods certain financial instruments not only protect the investor, but actually perform as a perverse hedge, i.e., decrease in value as inflation increases (Rubens et al, 1989) hence the need for both individual and institutional investors to determine the hedging potential of an asset before investing their money on assets.

According to the above paragraph, in an inflationary time periods long term investors face a regular problem about how to maintain the purchasing power of their assets over the investment time period and how to produce the maximum real return to achieve the investment objectives.

Barkham et al (1996) stated that the ability of an investment to protect against the erosion of real return due to increase in prices is vital in many ways. Further they are explaining that, for an individual, maintaining the real value of savings is important in order to protect the purchasing power for future needs. In a related way, it is important for investment managers to understand the ability of investments to hedge against inflation.

Maintaining economic and price stability of country has become one of the core objectives of Central Bank of Sri Lanka as in many other developing countries. 
The concern with maintaining price stability stems not only from the need to maintain overall macroeconomic stability, but also from the fact that price stability forms a better environment for investment, output, and employment etc. Over the decades, experience of many countries suggests that price stability promotes economic growth. Therefore policy makers believe, when inflation crosses a reasonable limit in the economy that can adversely affect other macroeconomic variables and in turn undermines its steady level of the economy (Kesavarajah, 2011).

Further Kesavarajah (2011) stated that recent years, experiences in both developed and developing countries have shown that rise in the price of essential commodities; particularly food and oil items affected almost all the countries in the world. Hence every country was under pressure to control the inflation level and the Central Banks of these countries have taken various measures to maintain the price stability. Sri Lanka's economy is not exceptional with respect to this issue since it heavily depends on these two items. Following the economic liberalization, the expansionary economic policies followed by the government and the Central Bank of Sri Lanka resulted in improvements in various macroeconomic indicators including economic growth, which remained above five percent. At the same time, continuous rise in the general price level in the economy has emerged an important macroeconomic problem all over the country.

It is evidenced that the short-run effects of price increases may seem small and negligible, but the long-run effects of inflation can be substantial. Long-term investors therefore prefer to invest in assets that provide some protection against increases in the general price level - especially pension funds, whose liabilities usually rise with inflation. To circumvent this financial catastrophe, regulators and policy makers experimented with unconventional tools, such as quantitative easing and stimulus packages, which might help overcome the recession but also are likely to instigate inflation. 